Received: 11.07.2021

Accepted: 05.08.2021

Published Online: 06.09.2021

DOI: 10.18613/deudfd.969098

Research Article
Dokuz Eylül University Maritime Faculty Journal

Special Issue: pp:109-133

E-ISSN: 2458-9942

\title{
EXERGY BASED SUSTAINABILITY ASSESSMENT OF AN ORC INTEGRATED WASTE HEAT RECOVERY SYSTEM FOR MARINE VESSELS
}

\author{
Olgun KONUR ${ }^{1}$ \\ Ömür Yaşar SAATÇIOĞLU² \\ Can Özgür ÇOLPAN ${ }^{3}$
}

\begin{abstract}
This paper introduces the basics of exergy-based sustainability assessment and the framework that should be shaped within the first stage. The sustainability assessment framework leads to sustainability indicators that are used to assist policymakers and decision-making processes. The literature review shows that the energy systems are suited to sustainability assessment with exergy based assessment tools and indicators from an environmental point of view. In this study, an exergy based sustainability assessment is carried out by using the exergy analyses results of an ORC (organic Rankine cycle) integrated waste heat recovery system on a 1,221 TEU container ship. The exergy analysis results are used to derive comparable and quantified exergetic sustainability indicators that indicate the sustainability level and further improvement potentials with the utilization of the proposed waste heat recovery system design. The assessment results show that the minimum waste exergy ratio is obtained with the value of 0.106 when R1234ze(Z) is used and the evaporating pressure is $3 \mathrm{MPa}$. R1234ze(Z) and R245fa working fluids show good environmental performance for the proposed system design. The maximum exergetic sustainability index value is obtained with the value of 8.435 when R1234ze(Z) is used and the evaporating pressure is $3 \mathrm{MPa}$.
\end{abstract}

Keywords: Sustainability, Exergy, Organic Rankine Cycle, Waste Heat Recovery, Marine Engineering.

1 Res. Asst., Dokuz Eylül University, Maritime Faculty, Izmir; Turkey, olgun.konur@deu.edu.tr (Corresponding author), ORCID ID: 0000-0002-26776048

2 Prof. Dr., Dokuz Eylül University, Maritime Faculty, Izmir; Turkey, yasar.saatci@deu.edu.tr, ORCID ID: 0000-0001-9054-2054

${ }^{3}$ Prof. Dr., Dokuz Eylül University, Mechanical Engineering Department, Faculty of Engineering, Izmir; Turkey, ozgur.colpan@deu.edu.tr, ORCID ID: 0000-0003$0855-3147$ 


\title{
DENIZ TAŞITLARI İÇİN ORC ENTEGRELİ BİR ATIK ISI GERI KAZANIM SISTEMININ EKSERJI TABANLI SÜRDÜRÜLEBİLİRLİK DEĞERLENDİRMESİ
}

\begin{abstract}
$\ddot{O} Z$
Bu çalışma, ilk aşamada ekserji tabanlı sürdürülebilirlik değerlendirmesinin temellerini ve içinde şekillendiği çerçeveyi tanıtmaktadır. Sürdürülebilirlik değerlendirmesi çerçevesi, politika yapıcılara ve karar verme süreçlerine yardımc olmak için kullanılan sürdürülebilirlik göstergelerine yönlendirmektedir. Literatür taraması, çevresel bir bakış açısından enerji sistemlerinin ekserji tabanl değerlendirme araçlarl ve göstergeleri ile sürdürülebilirlik değerlendirmesine uygun olduğunu göstermektedir. Bu çalışmada, 1.221 TEU'luk bir konteyner gemisi için tasarlanmış ORC (organik Rankine çevrimi) entegreli bir atık ısl geri kazanım sisteminin ekserji analiz sonuçlarl kullanılarak ekserji tabanl bir sürdürülebilirlik değerlendirmesi yapılmıştır. Önerilen atık ısı geri kazanım sistemi tasarımının sürdürülebilirlik düzeyini ve daha fazla iyileştirme potansiyelini ortaya koyan karşılaştırılabilir ve nicel ekserjetik sürdürülebilirlik göstergelerini türetmek için ekserji analizi sonuçları kullanılarak, kullanılmıştır. Değerlendirme sonuçları, minimum atık ekserji oranının 3 MPa'da 0,106 değerinde R1234ze(Z) akıskanından elde edildiğini göstermiştir. R1234ze(Z) ve R245fa iş akışkanlarl, önerilen sistem tasarımı için oldukça iyi bir çevresel performans göstermektedir. Maksimum ekserjetik sürdürülebilirlik indeksi 8.435 değerinde 3 MPa'da R1234ze(Z)'den elde edilmiştir.
\end{abstract}

Anahtar Kelimeler: Sürdürülebilirlik, Ekserji, Organic Rankine Çevrimi, Atık Isı Geri Kazanımı, Gemi Makineleri Işletme Mühendisliği.

\section{INTRODUCTION}

Sustainability assessment plays an important role in energy systems. The sustainability assessment tools on energy systems are beneficial at justifying an energy policy by discussing the effects of different sources of energy, determining the impact of waste energy and exergy on the environment, suggesting measures to reduce emissions, and encouraging the application of more environmentally benign solutions (Chowdhury et al. 2020a). A sustainable system refers to a system that does not cause permanent damage to the environment and does not consume excessive resources while performing an efficient operation for a long enough service period and leaving a clean environment and enough resources to posterity to meet their needs of natural resources (Dincer and Zamfirescu, 2018). Sustainable development of a system consists of challenges to achieve no or few negative environmental and social impacts goals, which require continuous and sustained improvement of the system. The sustainability of 
a system needs to be measured and assessed via sustainability assessment tools, thereby the system can be deduced as sustainable or indicate sustainable development (Hacatoglu et al. 2015).

Ness et al. (2007) categorized sustainability assessment tools into three areas that are indicators or indices, product-related assessment tools, and integrated assessment tools. Indicators are simple measures that can quantitatively represent the economic, social, and/or environmental state of a specified region. The sustainability trends are continuously tracked by calculating or measuring those indicators, which are utilized for short-term and future projections decision-making with a retrospective point of view. The product-related assessment tools include life cycle assessment, life cycle costing, material flow analysis, and product energy analysis. These tools identify inefficiencies and sustainability based risks about the product design and production processes. The integrated assessment tools are utilized for supporting decisions related to a policy or a project for managing complex problems from a prospective point of view. These tools might be used for a variety of applications in addition to sustainability assessment issues, e.g., system dynamics, risk analysis, cost-benefit analysis, vulnerability analysis, and environmental impact assessment (Dincer and Zamfirescu, 2018). The sustainability assessment tools have been adopted in many applications worldwide to track the environmental, economic, and social impacts of specific cases. These sustainability assessment case studies include electricity and heat production from solar energy, biofuel, hydrogen production, household energy needs, hydroelectric energy, waste heat recovery, and other energy sources; agriculture, food, forestry and other land use; transportation and automobile sectors; construction and building sectors; industrial sectors of ceramic, marble, solvents, wood, plastic, wind turbines, biorefinery, and chemicals (Visentin et al. 2020).

The sustainability assessment tools and relevant evaluations are further processed in a sustainability assessment framework to develop a strategy for the environmental impact of projects (Srinivasan et al. 2011). Drivers-pressures-states-impacts-responses (DPSIR) model has been a widely adopted framework, which acts as an adaptive management tool and describes the interactions between society and the environment (Kristensen, 2004; Walter, 2013). In this model, the casual links start with the drivers that indicate the developments in society, the economy, and the environment. The driving forces exert pressure on the current state of sustainability, which leads to impacts resulting from changes in the environmental quality in any direction. Society plays an important role in this model, where they can give responses to this change to reverse the impacts. In addition, the responses of society can directly act on the drivers, 
pressures, or state of sustainability with feedback loops, as illustrated in Figure 1 (Gabrielsen and Bosh, 2003; Dincer and Zamfirescu, 2018).

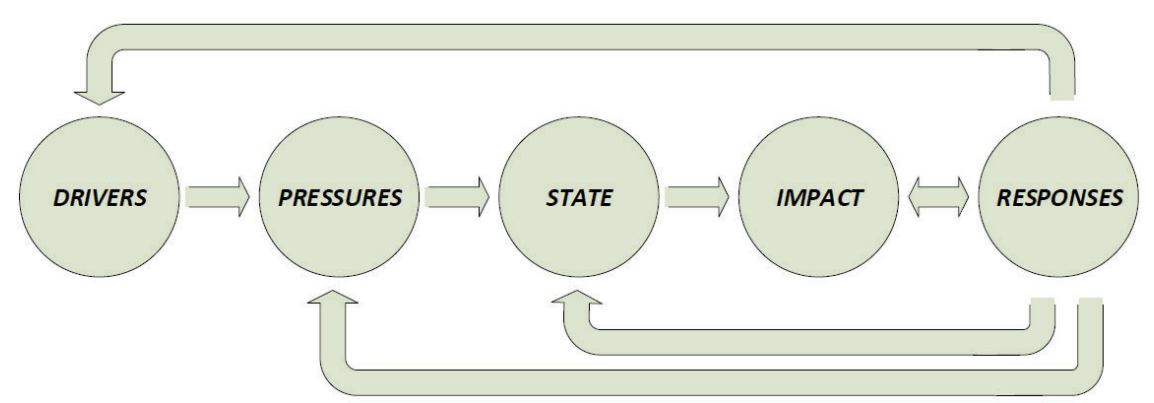

Figure 1: DPSIR Model for Sustainability Assessment Source: Adapted from Dincer and Zamfirescu, 2018.

Sustainability indicators are characterized by their duties in the DPSIR model. From an energy system perspective, those indicators shape the direction of sustainable development strategies with the help of assessment of and advancement in technology. Fossil fuel-dependent economy in present and the developing technological advancements create social and environmental driving forces that cause a change in the current state of the sustainability of energy systems. The policy and decisionmaking process can be supported with the sustainability assessment indicators that are measured for the current state and technologically advanced state causing another pressure branch for sustainable development. The response should be capable of achieving a more sustainable society for the future. In some cases, this goal can be a driving pressure that creates feedbacks through policy-making for the need for more advanced technologies to create more sustainable solutions for the future. The role of sustainability indicators of energy systems for a planned sustainable energy society is introduced by Dincer and Zamfirescu (2018) and modified as illustrated in Figure 2.

An energy system consists of resource and process enabler inputs, and in return produces actual process outputs and wastes. Process outputs can be defined as the combination of utilizable exergy and recyclable streams like recoverable heat, emissions, or utilities (Linke et al. 2014). The sustainability of a system can be determined by measuring the wastes produced by the process. The wastes of an energy system generally show themselves in the form of pollutants emissions, waste energy, or material wastes. The energy analyses measure the waste energy according to the given inputs to the system. However, a direct measure of energy efficiency will not cover the effects of heat losses on the environment. In this context, 
exergy analyses become more reliable in the sustainability assessment of energy systems because the exergy of a system covers environmental factors as a reference.

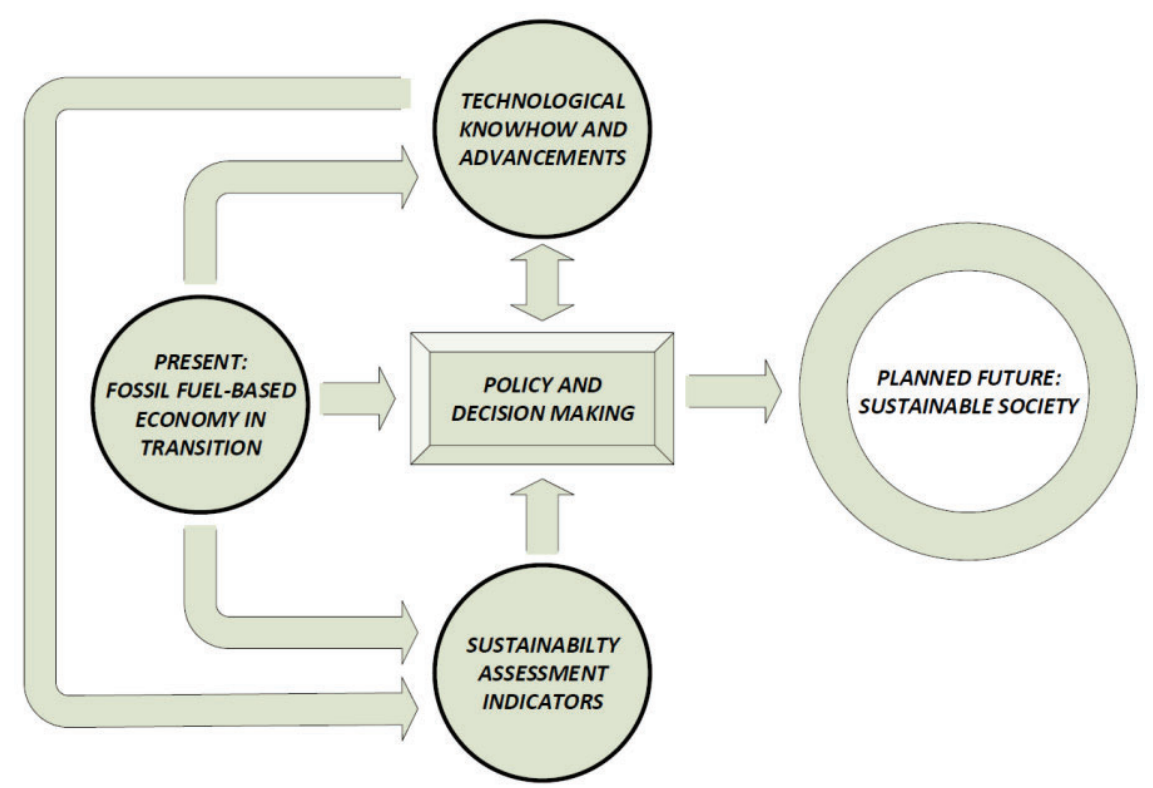

Figure 2: The Role of Sustainability Assessment Indicators of Energy Systems for A Planned Sustainable Energy Society Source: Adapted from Dincer and Zamfirescu, 2018.

Instead of using the first law of thermodynamics (energy analysis), exergy and emergy analyses are more advanced since they consider both the quality and the quantity of energy (Rosen and Dincer, 2001). The exergy of a system is the maximal amount of mechanical work that can be extracted (Wall, 1977). In terms of evaluating the efficiency, loss, and performance of a system, exergy analysis is more useful than energy analysis (Caliskan et al. 2011). Exergy analysis offers to represent a true measure of imperfections of an energy system and indicate possible ways to improve the energy systems, which in turn forms a basis for sustainability assessment of the system subjected to the analysis from the environment. Assessment of the exergy destruction offers the opportunity to quantify the environmental impact and the sustainability of any energy system (Dincer and Zamfirescu, 2018). Also, the exergy analysis has been applied to different engineering fields thereby bringing understanding to the actual losses involved in energy conversion processes and sustainability level of energy systems (Rosen et al. 2008; Midilli et al. 2012; Aydin, 2013; Gingerich and Mauter, 2015; Turan and Aydin, 2016; Abam et al. 2017; Abam et al. 2018a). 
This study aims at indicating comparable quantified data with the assessment results that show sustainability improvement potentials if the ORC integrated waste heat recovery system design proposed by Konur et al. (2020) is applied. It is expected that the quantified sustainability assessment results will help decision-making processes of policymakers and ship owners to apply ORC systems to marine vessels for more energyefficient and environment-friendly operations.

\section{LITERATURE SURVEY ON EXERGY BASED SUSTAINABILITY ASSESSMENT OF ENERGY SYSTEMS}

The focus of exergy-based sustainability assessment studies in the early stages was gathered around new technological options for small-scale home applications. The studies for industrial applications were then rapidly increased as the method reveals comparative data for the existing/developing technological options and further improvement potentials of their components. Balta et al. (2010) investigated the performance of four energy options for building HVAC systems, which are ground heat pump, condensing boiler, conventional boiler, and solar collector systems. They aimed to assess the most sustainable system among those four systems by comparing the SI values for all cases at varying reference outdoor temperatures of -10 to $15{ }^{\circ} \mathrm{C}$, and a target indoor temperature of $20^{\circ} \mathrm{C}$. The results indicate that the most sustainable system among those four is the solar collector heating system for the case study of the reference building. Total exergy efficiencies of the heat pump, condensing boiler, conventional boiler, and solar collector for the reference outdoor temperature of $0{ }^{\circ} \mathrm{C}$ are $3.66,3.31,2.91$, and $12.64 \%$ with the sustainable index values of $1.039,1.034,1.030$, and 1.144 , respectively. The results also showed that the solar collectors perform a better sustainability graphic for colder ambient temperatures that can reach above 1.40 at $-10^{\circ} \mathrm{C}$. Caliskan et al. (2011) conducted a sustainability assessment study of a solar-ground based heat pump with thermal energy storage for a case study of a $120-\mathrm{m}^{2}$ house. The study aimed to obtain the sustainability aspects of the system for varying reference temperatures of 0 to $25^{\circ} \mathrm{C}$. It was indicated that the exergy efficiency, as well as the sustainability index, is inversely proportional to the reference temperature. Therefore, the obtained SI rate values were bigger at $0{ }^{\circ} \mathrm{C}(1.6946)$ than $25{ }^{\circ} \mathrm{C}(1.6193)$ reference temperatures.

Caliskan and Hepbasli (2011) carried out an exergy-based sustainability assessment to a four-stroke diesel engine for the running up conditions with diesel oil no. 2 and two different kinds of biodiesels (soy methyl ester and high-oleic methyl ester). It was found that using 
biodiesels shows a better sustainability performance than those of diesel no.2. Using the $0{ }^{\circ} \mathrm{C}$ reference temperature, the obtained average SI rates were $1.6015,1.6116,1.6097$ for diesel no.2, soy methyl ester and higholeic methyl ester fuels, respectively. Wu et al. (2015) investigated the renewability and sustainability of household biogas utilization in rural areas of China by using a cosmic exergy based assessment approach that aggregates natural resources, economic inputs and environmental contamination on a common basis. The results indicate that the integrated biogas system nearly doubles the ecological benefits based on a 20 -years of lifespan scenario when compared to the conventional production system. Maniali and Silveira (2015) compared the sustainability of different energy options for rural area electrification. They select eleven indicators among economic, environmental, social, technical and institutional pillars of sustainability. The method for evaluating the sustainability indicators was mainly based on normalizing the data for those indicators found in the literature. Ten technologies among the most suitable options for rural areas were investigated for 2005, 2010 and 2015, respectively. The results enabled the investigation of the examined technologies from different indicator perspectives using a radar diagram. The sustainability performance was further investigated by calculating energy technology sustainability indexes for those technologies. It was shown that diesel generators were still a good option but placed fifth among these technologies. Biomass and micro/pico hydroelectric power have resulted as more sustainable options than others for rural area electrification. It has also resulted that the emerging technologies, such as solar and wind energy options, possessed lower sustainability performances but have been increasing their sustainability performance for the years from 2005 to 2015. It would be an interesting study to assess the performance of those technologies considering the new developments through 2020.

Energy, exergy and exergoeconomic analyses with sustainability and environmental analyses have been a hot topic in aviation for different aircraft engines (Balli and Hepbasli, 2014; Aydin et al. 2015; Turan and Aydin, 2016; Şöhret et al. 2016; Ekici et al. 2018; Baklacioglu et al. 2018; Sögüt, 2018; Sahu et al. 2018; Aygun and Turan, 2020; Yuksel et al. 2020). The analyses results of these studies are utilizable as a guide for the design and improvement efforts of the aircraft engines. The major losses from the parts of the aircraft engines were obtained by the energy and exergy analyses. The environmental effect and the sustainability of the engine were assessed using the environmental effect factor and exergetic sustainability index. Waste exergy ratio, recoverable exergy ratio and exergy destruction factor were other metrics that were taken into consideration while indicating the sustainability of the aircraft engines. 
Sustainability analysis of the aircraft engines was investigated in a wider perspective in some of these studies with the calculation of the sustainable cost index (SCI), which is the ratio of unit exergy cost of products to the sustainability index. It is mentioned that the methods for lowering the SCI value are sought by investigating the effect of parameters such as; system's product cost flow, exergy efficiency, SI, fuel cost rate, total capital investments (Sahu et al. 2018).

There can be found several studies that were adopted the sustainability index method for the sustainability assessment of cogeneration and tri-generation power plants for various areas. Ozcan and Dincer (2014) analyzed a tri-generation system consisting of parabolic trough solar collectors, an ORC, an absorption chiller and a thermal energy storage system. They obtained that the sustainability of the system improves with higher solar irradiation and lower ambient temperature. The results also showed that the plant performance is strongly dependent on the solar collector design and operational parameters of mass flow rate, pressure ratios and specified target temperatures of the tri-generation system components. Acar and Dincer (2014) utilized the exergetic sustainability index method to investigate the further development potential of the components of zero-emission power plants for coproduction of electricity and methanol. The analyses were carried out for the water electrolysis unit, methanol synthesis unit, overall power plant, at which the index results were found as $1.43,1.7,2.43$, respectively. They found that the ambient temperature does not have a significant effect on the exergetic performance of the system. They also suggested using turbines driven by combustion gases to meet the work requirements of the electrolysis unit and recover the waste heat to increase the exergy efficiency of the total system by 3\%. Caglayan and Caliskan (2018) proposed a cogeneration system for the ceramic industry that can both produce electrical power through a gas turbine and also provide waste heat to be utilized in drying processes. The sustainability index values of cogeneration plant components provided an improvement opportunity by analyzing the system model with varying dead state temperatures. The results showed that the sustainability of the overall cogeneration plant is directly proportional to the ambient temperature, which scores better at 30 ${ }^{\circ} \mathrm{C}$ with the sustainability index of 1.4282 . Nami and Anvari-Moghaddam (2020) investigated tri-generation systems for waste heat recovery from cement plants in exergo-sustainability and economic aspects. Recuperative ORC and steam Rankine cycle systems were considered as power generation options for the proposed combined cooling, heating and power (CCHP) system designs. As the cooling demand of the plant seasonally varies, the two system configurations were compared according to the cooling demand. The results of the study showed that the ORC-based 
CCHP system has better sustainability performance, but has a higher payback period than the Rankine-based CCHP system.

Stougie (2014) proposed a method called "Total Cumulative Exergy Loss (TCExL)" that takes into account all exergy losses of a system during its lifecycle. The method is used to assess the exergetic sustainability of a system by calculating internal exergy losses including the abatement exergy for the emissions of $\mathrm{NO}_{\mathrm{x}}, \mathrm{SO}_{2}, \mathrm{CO}_{2}$, and phosphate. The reference abatement exergy values were taken from the literature that has been carried out with the abatement technologies of the years between 19972011, which were only able to remove a certain amount of the emissions (from 80 to 99\%). As the abatement technologies improve, the reference values would need to be updated. The exergy losses caused by the land use is based on the exergy that becomes unavailable to the ecosystem because of the occupied land area for the system. The exergy loss caused by land use is calculated by the multiplication of average solar irradiation dropped to the occupied area with the efficiency of capturing solar energy via photosynthesis and the amount of exergy per amount of sunlight. The study also investigated a case study of power generation with a coal-fired power plant and the integration of ORC and LNG evaporation systems for utilizing the waste heat of the power plant. The sustainability assessment included economic, environmental and social aspects and a comparison of the results for varying TCExL has been carried out. The results showed that exergetic losses of the system inversely affect all of the sustainability scores, but have a much higher impact on the economic indicators. The method was also utilized in Stougie et al. (2018) for the sustainability assessment of power generation from biomass with environmental aspects. Bioethanol, anaerobic digestion and supercritical water gasification systems were assessed using the calculated exergetic sustainability and $\mathrm{ReCiPe}$ scores. The results of the environmental and exergetic sustainability assessments showed that the bioethanol system can be preferred among the other options, but the difference in the scores was not large.

ORC systems are one of the widely adopted technology for WHR. The system can be integrated into many applications, such as cogeneration, tri-generation and stand-alone plants as an electrical power generation option. Because the ORC is still an emerging technology, studies for ORC system utilization have been increasing in the last few years. Baral et al. (2015) studied the thermoeconomic performance of solar organic Rankine cycle (SORC) systems. They investigated the sustainability development through SORC systems by comparing the saved petroleum for electricity generation with petroleum-based plants. Exergy based sustainability was also investigated in this study to assess the most sustainable system 
configuration for different solar source temperatures of the SORC system, which is concluded as higher solar source temperatures give better sustainability index results. Ataei et al. (2015) investigated the thermodynamic performance and exergetic sustainability of simple, regenerative, recuperative, and combined ORC systems with R113, RC318, iso-pentane and n-hexane working fluids. They concluded that a combined regenerative and recuperative ORC system with $\mathrm{n}$-hexane working fluid showed the best performance among the examined configurations. The results also showed that the sustainability index of the ORC system slightly increases for reducing ambient temperatures. A research group from Nigeria published a set of environmental and exergetic sustainability assessment studies of various ORC configurations for varying operating system parameters (Abam et al. 2017; Abam et al. 2018a; Abam et al. 2018b; Abam et al. 2018c). These studies mainly focused on the exergy efficiency and exergy destruction rates of ORC system components at varying evaporator pressures, turbine inlet temperatures and heat source temperatures. The research group also investigated the performance of different organic working fluids for varying operational parameters. They also presented comparable results for exergetic sustainability assessment of the ORC systems by calculating the waste exergy ratios, environmental effect factors, exergetic sustainability indexes for different ORC working fluid and operational parameters.

The sustainability of different ORC system configurations for marine vessels was also investigated from exergetic, economic and environmental points of view. Kalikatzarakis and Frangopoulos (2015) carried out a multi-criteria evaluation of different ORC system configurations that are designed for a large marine vessel and using the waste heat of the main diesel engine's lubricating oil, jacket cooling water and charge air cooler as the heat source. Economic criteria (initial investment, net present value, dynamic payback period, and internal return rate), environmental criteria $\left(\mathrm{CO}_{2}, \mathrm{NO}_{\mathrm{x}}\right.$, and $\left.\mathrm{SO}_{\mathrm{x}}\right)$ and technical criteria (power output, total energy efficiency, and total exergy efficiency) were evaluated to find out the optimized system design parameters by operational and design optimizations for achieving a better sustainability performance with the ORC system. Tsougranis and $\mathrm{Wu}$ (2018) studied the feasibility of power generation with ORC systems by using the thermal and cryogenic waste heat energy of LNG powered marine vessels. The proposed ORC system is a simple ORC design consisting of an evaporator using the waste heat exhaust gas emitted from the main engine and a condenser that utilizes the cold waste heat of LNG fuel as the cooling utility before it is supplied to the main engine. Energy, exergy, economic and sustainability assessment analyses were carried out for single-stage and two-stage regenerative ORC system configurations utilizing organic 
working fluids with low melting points. They calculated a payback period of 4 years for both configurations. The results showed that ethylene $\left(\mathrm{C}_{2} \mathrm{H}_{4}\right)$ working fluid performs better for condensing pressures above $1.1 \mathrm{bar}$. The sustainability assessment results for $\mathrm{C}_{2} \mathrm{H}_{4}$ working fluid indicate a $12.1 \%$ higher sustainability index value for two-stage regenerative ORC configuration in comparison with single-stage regenerative ORC configuration. Jankowski and Borsukiewicz (2020) defined another exergetic sustainability indicator, which they called the exergy utilization index (XUI). The index is used to indicate how much of the heat source exergy is utilized. As the heat source outlet temperature gets closer to the ambient temperature, the XUI is maximized, which is also resulted in a minimization of the exergy waste to the environment. A parametric study was carried out in their study to reveal the relationship between XUI and other exergy based indicators for an ORC system utilizing geothermal energy. Higher values of XUI increased the exergy-based indicators as expected. However, the payback period of the system is minimized between $60-80 \%$ XUI values for the optimal operating conditions of the ORC system.

The literature review shows that the exergetic sustainability indicators have been well introduced and the related studies were mostly applied for industrial-scale applications of energy systems. Although marine vessels are subjected to increasing demand for energy efficiency improvements, exergetic sustainability assessment for those energy efficiency improving techniques still lacks in the literature. The increasing number of these studies would provide comparable data for implementing systems to marine vessels with better sustainability performance.

\section{METHODOLOGY}

The literature review shows that the exergy analyses and exergetic sustainability indicators have been successfully implemented as a tool to assess the sustainability of energy systems. In the present case, an ORC integrated HEN design proposed by Konur et al. (2020) for multiple heat sources located on a 1,221 TEU container ship using real data sets of the vessel is utilized to assess the exergy-based sustainability of reference vessel with the proposed HEN design. The exergy analyses have been carried out using the verified thermodynamic model in the study of Konur et al. (2020). The layout of the proposed ORC integrated HEN (heat exchanger network) design of the reference ship's heat collection system and ORC system is shown in Figure 3. 


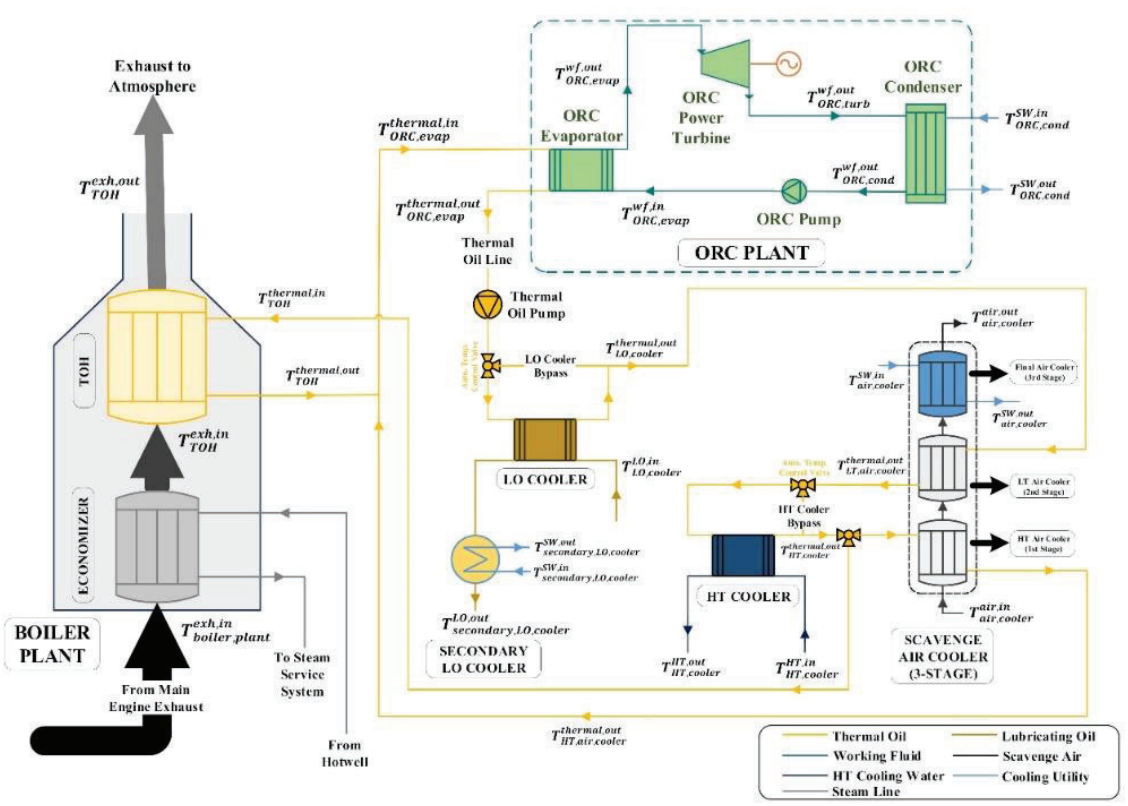

Figure 3: Layout of The Integrated Optimal HEN and ORC System for The Reference Ship

Source: Adapted with permission from Konur et al. 2020. Copyright 2020, John Wiley and Sons. License number: 5104801401995.

The exergy-based parameters for a system or equipment reveal how their operating conditions and system characteristics affect sustainability (Balli and Hepbasli, 2014; Turan et al. 2014). Some examples of exergetic sustainability indicators can be given as exergy efficiency, waste exergy ratio, recoverable exergy ratio, exergy destruction factor (depletion number), environmental effect factor, exergetic sustainability index, sustainability index, exergy utilization factor, lack of productivity, relative irreversibility, and exergo-emission indicator. These indicators are used to quantify the sustainability of a system or equipment. In addition, the quantified data assist decision-making processes for further increase in the efficiency of the system or the equipment and more environmentally benign and sustainable solutions (Turan and Aydin, 2016; Maniali and Silveira, 2015).

The exergy analyses results are used to derive exergetic sustainability indicators, which show the sustainability levels and improvement potentials with the utilization of the proposed ORC integrated waste heat recovery system design. The sustainability indicators of exergy efficiency, waste exergy ratio, environmental effect factor, environmental destruction coefficient, exergetic sustainability index, 
sustainability index, and improvement potential are investigated in this study. The analyses are carried out for the propulsion engine loads of 100 , 75,50 , and $25 \%$ MCR (maximum continuous rating) for nine different environmentally-friendly working fluids of as given in Table 1 to assess the most sustainable option for the proposed ORC system design.

Table 1: Properties of The Selected Organic Working Fluids

\begin{tabular}{|c|c|c|c|c|c|c|c|c|c|}
\hline & R1234ze(Z) & R245fa & R600 & R236ea & Isobutane & R236fa & R152a & R134a & R1234yf \\
\hline GWPa $^{\mathbf{a}}$ & $<1$ & 1,030 & 4 & 1,200 & 3 & 9,400 & 124 & 1,430 & 4 \\
\hline ODP $^{b}$ & 0 & 0 & 0 & 0 & 0 & 0 & 0 & 0 & 0 \\
\hline $\begin{array}{l}\text { ASHRAE } \\
34^{\mathrm{c}}\end{array}$ & $\mathrm{A} 2 \mathrm{~L}$ & $\mathrm{~A} 1$ & A1 & A1 & A3 & A1 & $\mathrm{A} 2$ & A1 & $\mathrm{A} 2 \mathrm{~L}$ \\
\hline $\begin{array}{l}\text { Critical } \\
\text { Temp. } \\
\left({ }^{\circ} \mathrm{C}\right)\end{array}$ & 150.1 & 154.0 & 152.0 & 139.3 & 134.7 & 124.9 & 113.3 & 101 & 94.7 \\
\hline $\begin{array}{l}\text { Critical } \\
\text { Press. } \\
\text { (kPa) }\end{array}$ & 3,533 & 3,651 & 3,796 & 3,429 & 3,640 & 3,200 & 4,520 & 4,059 & 3,382 \\
\hline $\begin{array}{r}{ }^{\mathrm{a}} \mathrm{GWP} \text { : globa } \\
\text { bDP: ozone } \\
\text { So } \\
\text { Ex } \\
\text { flammable; } \\
\text { integratec } \\
\text { Equation } \\
\text { 2018; Ch }\end{array}$ & $\begin{array}{l}\text { Standard } 34 \\
\text { 2: Lower flam } \\
\text { urce: Refr } \\
\text { dergy base } \\
\text { d WHRS } \\
\text { s 1-7 (Ayc } \\
\text { lowdhury }\end{array}$ & $\begin{array}{l}\text { - Refriger } \\
\text { nmability; } \\
\text { rigerant } \\
\text { ed sust } \\
\text { for the } \\
\text { din, } 201 \\
\text { et al. } 2\end{array}$ & $\begin{array}{l}\text { 3: High } \\
\text { t Repo } \\
\text { tainab } \\
\text { e refe } \\
13 \text {; Tu } \\
020 \mathrm{~b} \text {; }\end{array}$ & $\begin{array}{l}\mathrm{o}^{\circ} \mathrm{CO}_{2} \text { o } \\
\text { o } 11 \text {. } \\
\text { fety group } \\
\text { her flamm } \\
\text { ort, } 202 \\
\text { oility a } \\
\text { rence c } \\
\text { uran an } \\
\text { Jankov }\end{array}$ & $\begin{array}{l}\text { p classificati } \\
\text { tability; A: L } \\
\text { 20; Linde } \\
\text { assessmer } \\
\text { container } \\
\text { d Aydin, } \\
\text { wski and }\end{array}$ & $\begin{array}{l}\text { ion. 1: N } \\
\text { ower tox } \\
\text { Indust } \\
\text { nt of } \\
\text { ship } \\
2016 \text {; } \\
\text { Borsuk }\end{array}$ & $\begin{array}{l}\text { Non-flamı } \\
\text { kicity; B: } \\
\text { trial Ga } \\
\text { the pr } \\
\text { is carr } \\
\text { Tsoug } \\
\text { kiewicz }\end{array}$ & $\begin{array}{l}\text { Imable; } 2 \\
\text { Higher to } \\
\text { ases, } 2 \\
\text { ropose } \\
\text { ried ou } \\
\text { ranis a } \\
z, 202\end{array}$ & $\begin{array}{l}\text { 2L: Mildly } \\
\text { toxicity. } \\
2021 . \\
\text { d ORC } \\
\text { ut using } \\
\text { and Wu, } \\
0)\end{array}$ \\
\hline
\end{tabular}

$$
\text { Exergy efficiency, } \eta_{\mathrm{ex}}=\frac{\text { Total useful exergy output }}{\text { Total exergy inlet }}
$$

Waste exergy ratio, WER $=\frac{\text { Total exergy destruction }+ \text { Total exergy loss }}{\text { Total exergy inlet }}$

$$
\text { Environmental effect factor, } \mathrm{EEF}=\frac{\mathrm{WER}}{\eta_{\mathrm{ex}}}
$$

Environmental destruction coefficient, $\mathrm{EDC}=\frac{1}{\eta_{\mathrm{ex}}}$

$$
\text { Exergetic sustainability index, } \mathrm{ESI}=\frac{1}{\mathrm{EEF}}
$$

$$
\text { Sustainability index, } \mathrm{SI}=\frac{1}{1-\eta_{\mathrm{ex}}}
$$

Improvement potential, IP $=\left(1-\eta_{\mathrm{ex}}\right) \cdot($ Exergy inlet-Exergy output $)$ 


\section{EXERGY BASED SUSTAINABILITY ASSESSMENT RESULTS OF THE ORC INTEGRATED WHRS FOR THE REFERENCE CONTAINER SHIP}

In this section, exergy based sustainability assessment of the proposed ORC integrated WHRS for the reference container ship is carried out using Equations 1-7. It is aimed to provide exergetic sustainability indicators for assisting decision-making processes of ship owners, engine and ORC system manufacturers that consist of decisions of implementing the proposed system design and which performance parameters should be used to achieve a better sustainability performance.

As one of the sustainability indicators, the exergy efficiency of the proposed ORC system design has been calculated in the study of Konur et al. (2020) using Equation 1 as an output of the conducted exergy analysis. The results have been given in Figure 4 for varying ORC evaporator pressures and different types of ORC working fluids.

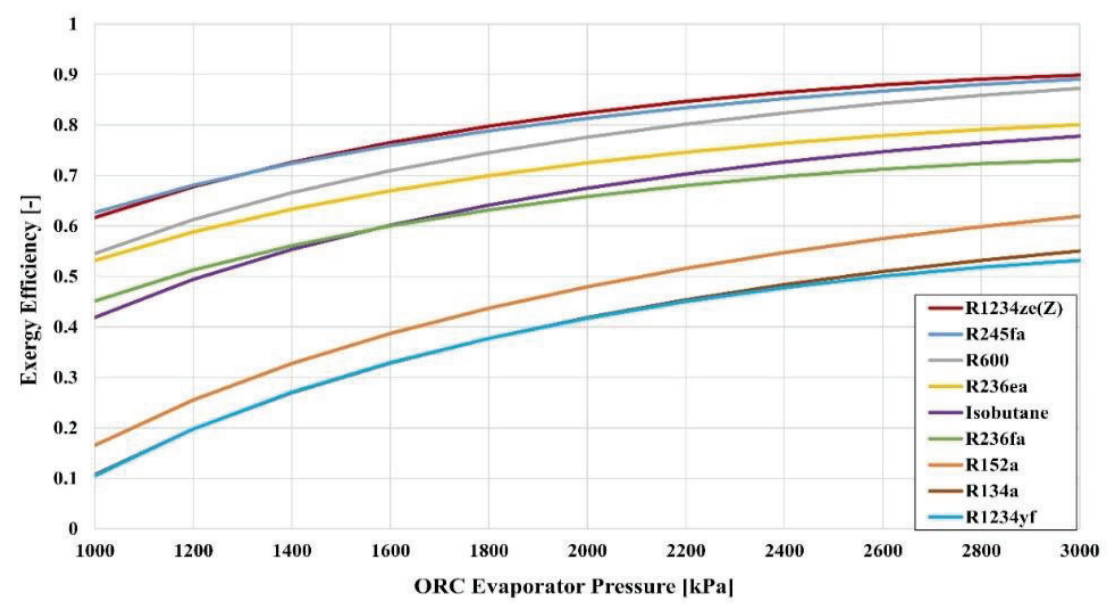

Figure 4: The Effect of Evaporator Pressure and ORC Fluid Type on The Exergy Efficiency of The System

Source: Adapted with permission from Konur et al. 2020. Copyright 2020, John Wiley and Sons. License number: 5104801401995.

Waste exergy ratio (WER) is defined as the ratio of total waste exergy to the total exergy inlet of the system. Total waste exergy is found as the sum of total exergy destruction from the ORC system and heat losses to the surroundings as in Equation 2. Total exergy inlet to the ORC system is the exergy inlet from the ORC evaporator to the ORC system. The effect of ORC evaporator pressure on WER for nine different working fluids are 
investigated and the results are presented in Figure 5. It can be deduced that WER is inversely related to the exergy efficiency of the ORC system. The maximum value of WER is obtained as $89.5 \%$ for R $1234 \mathrm{yf}$ at 1,000 $\mathrm{kPa}$, which shows the worst performance following the results obtained from the energy and exergy analyses. The WER is minimum for $\mathrm{R} 1234 \mathrm{ze}(\mathrm{Z})$ at $3 \mathrm{MPa}$ with the value of $10.6 \%$, but $\mathrm{R} 245 \mathrm{fa}$ starts to perform better for ORC evaporator pressures less than 1,600 $\mathrm{kPa}$.

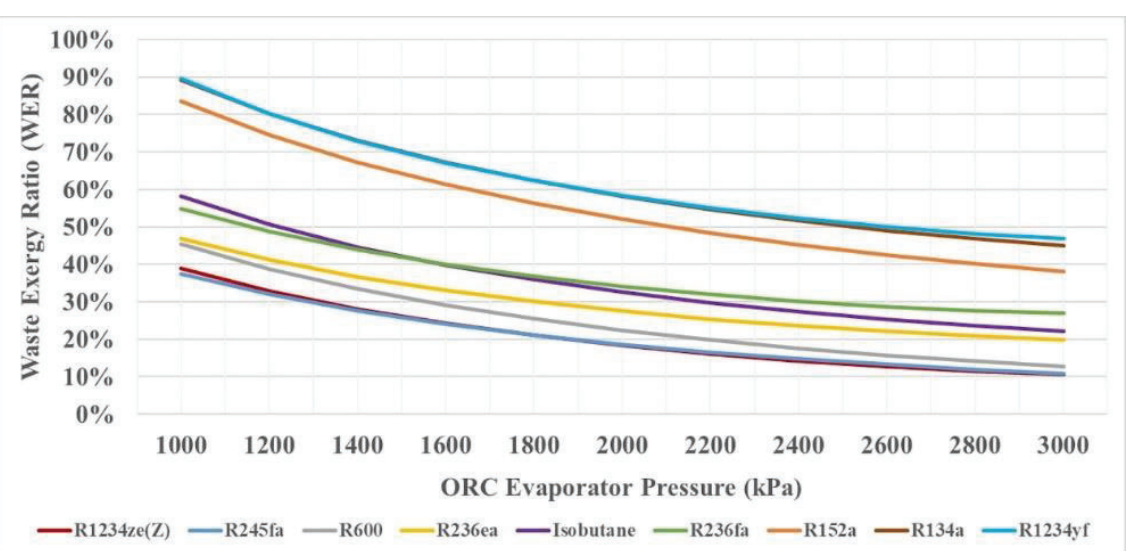

Figure 5: WER Values Obtained for Different Evaporator Pressures and Working Fluids

Environmental effect factor (EEF) indicates whether the energy conversion system gives harm to the environment. EEF of a system is expected to increase with increased waste exergy output and reduced useful exergy output. EEF values for the proposed ORC integrated WHRS are calculated using Equation 3. The environmental destruction coefficient (EDC) is inversely proportional to the exergy efficiency of the system as can be seen in Equation 4. EDC shows a similar pattern with the EEF as they are both affected by the exergy efficiency. In the sustainability perspective, EEF should be as close as to 0 (zero) that indicates the waste exergy of the system is minimized however, EDC values can vary between 1 to infinity and a system with EDC of closer to 1 will result in more sustainable operation. The EEF and EDC values calculated for the proposed system design are depicted in Figure 6 and Figure 7. R1234ze(Z) and R245fa working fluids show good environmental performance in this design with EEF values of 0.167 and 0.174 at the selected operating pressure of 2,400 $\mathrm{kPa}$, respectively. EDC values are calculated as 1.666 and 1.173 at the same conditions. The environmental effects can be further reduced with the increased evaporator pressure. 


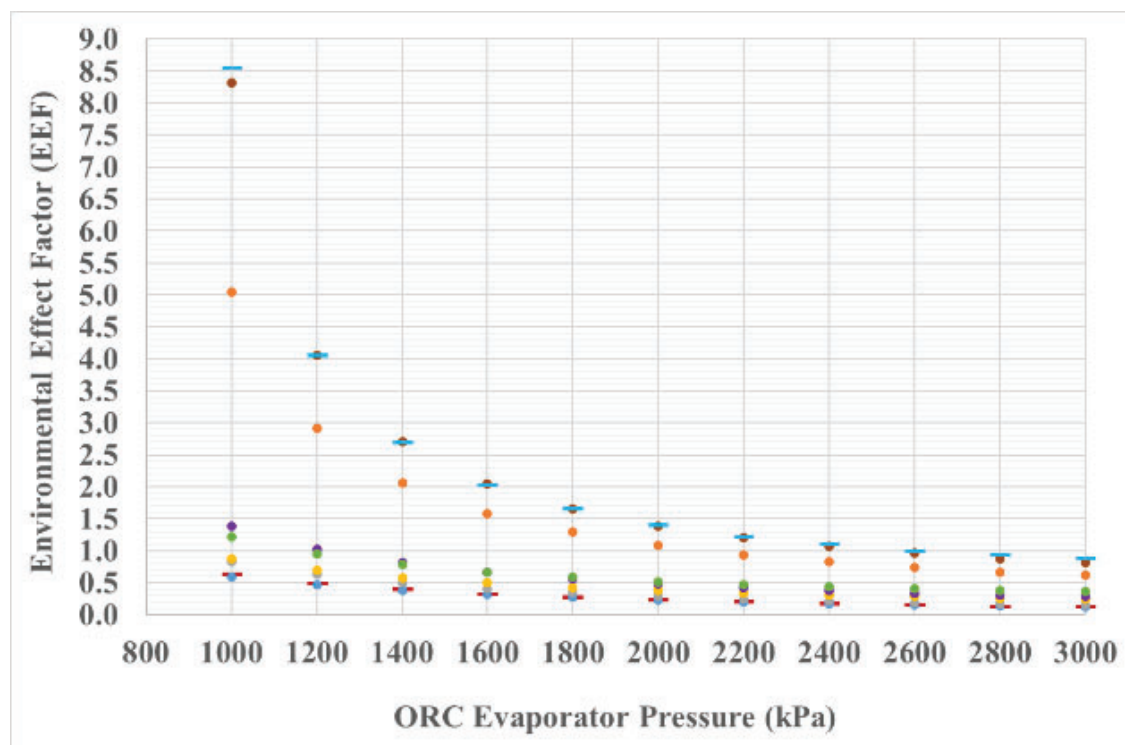

$-\mathrm{R} 1234 z e(Z) \cdot \mathrm{R} 245 \mathrm{fa} \cdot \mathrm{R} 600 \cdot \mathrm{R} 236 \mathrm{ea} \cdot$ Isobutane $\cdot \mathrm{R} 236 \mathrm{fa} \cdot \mathrm{R} 152 \mathrm{a} \cdot \mathrm{R} 134 \mathrm{a}-\mathrm{R} 1234 \mathrm{y} f$

Figure 6: EEF Values Calculated for Different Evaporator Pressures and Working Fluids

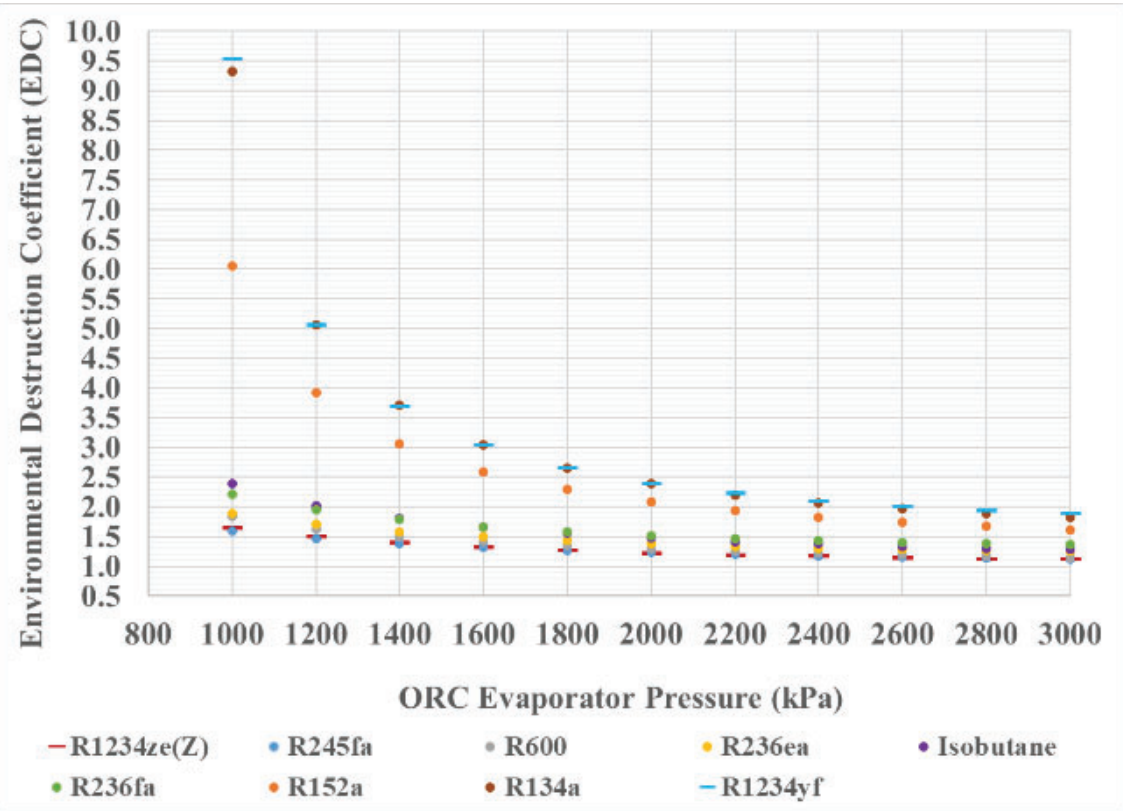

Figure 7: EDC Values Calculated for Different Evaporator Pressures and Working Fluids 
The exergetic sustainability index (ESI) and Sustainability index (SI) are among the most used exergy based sustainability indicators that indicate the degree of sustainability. ESI and SI work in a similar correlation as between EEF and EDC. ESI is the inverse of EEF as given in Equation 5; thereby directly affected by the exergy efficiency of the system. ESI varies between 0 and infinity, while SI values are between 1 and infinity according to Equation 6. As the system efficiency gets higher, lower waste exergy ratios and environmental effects as a result higher SI and ESI are achieved. The calculated ESI and SI values are given in Figure 8 and Figure 9, respectively. The maximum ESI and SI values are obtained from $\mathrm{R} 1234 \mathrm{ze}(\mathrm{Z})$ at $3,000 \mathrm{kPa}$ at the value of 8.435 and 9.435 . For the selected operating pressure of $2,400 \mathrm{kPa}$ and working fluid of R245fa, the calculations show ESI and SI values of 5.764 and 6.764 .

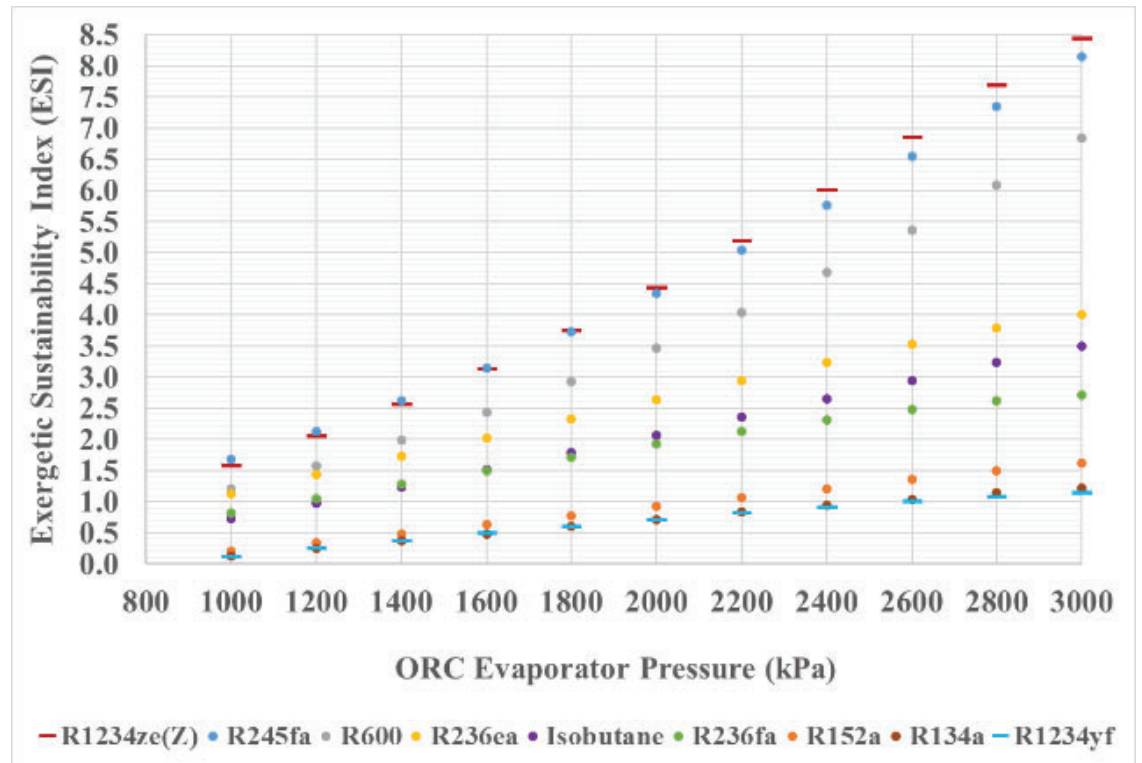

Figure 8: ESI Values Calculated for Different Evaporator Pressures and Working Fluids 


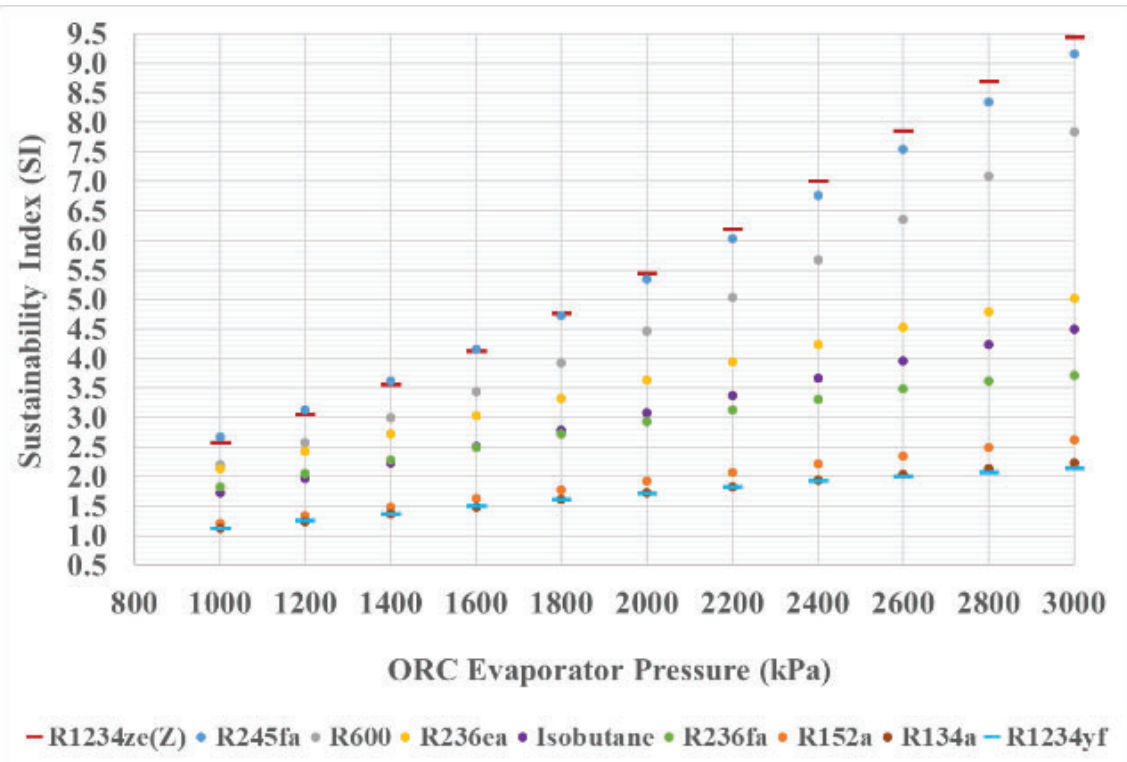

Figure 9: SI Values Calculated for Different Evaporator Pressures and Working Fluids

Improvement potential (IP) shows how much more work could have been generated by the given exergy input to the system. IP indicator depends on the exergy efficiency with the exergy inputs and outputs as can be seen in Equation 7. The difference between the exergy inlet and output is constant at each engine load category for varying working fluid types because the heat flow to the ORC evaporator is limited by the target temperatures of the thermal oil side. It means that the higher exergy efficiency values lead to lower IPs as illustrated in Figure 10. As the engine load increases, the exergy input to the ORC system also increases and leaves more improvement potentials for each working fluid type. 


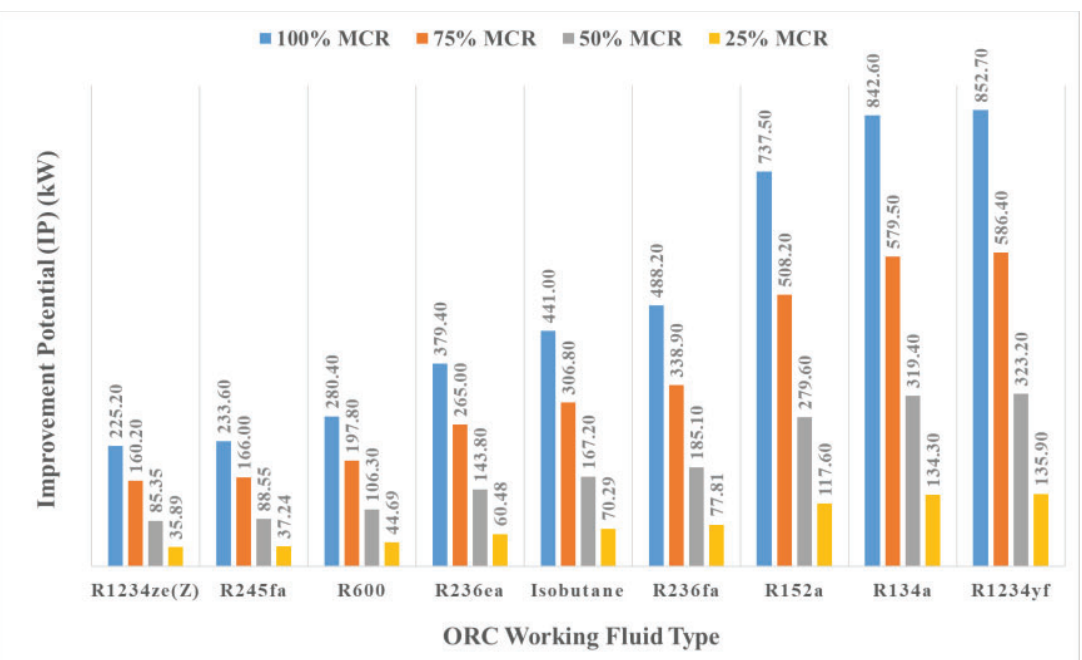

Figure 10: IP for Different Engine Loads and Working Fluids at ORC Evaporator Pressure of $2,400 \mathrm{kPa}$

\section{CONCLUSIONS}

In this study, the sustainability of the ORC integrated WHRS design is assessed using exergetic sustainability indicators of WER, EEF, EDI, ESI, SI, and IP. The assessment was also carried out for organic working fluids among different environmentally friendly alternatives and a proper evaporating pressure by using parametric analyses. The minimum WER is obtained from R1234ze(Z) at $3 \mathrm{MPa}$ with a value of 0.106 . R1234ze(Z) and R245fa working fluids show good environmental performance for the proposed system design with EEF values of 0.167 and 0.174 at the selected operating pressure of $2,400 \mathrm{kPa}$. The maximum ESI values are obtained from R1234ze(Z) and R245fa at 3,000 $\mathrm{kPa}$ at the value of 8.435 and 8.154, respectively. The ESI value R245fa at $2,400 \mathrm{kPa}$ is calculated as 5.764 . As the engine load gets higher, more IP is left out from the system. In addition, IP reduces with the increased exergy efficiency as expected.

This study aims at indicating comparable quantified data with the assessment results that show sustainability improvement potentials if the ORC integrated WHRS design. The sustainability assessment is carried out using the exergetic sustainability indicators to indicate the sustainability level of the proposed system with normalized indicators. The sustainability assessment results will be beneficial at justifying an energy policy for policymakers, determining the impact of waste energy and exergy to the environment with and without the proposed system, and encouraging the ship owners to the utilization of ORC integrated WHRSs for marine applications as an environmentally benign option. 


\section{REFERENCES}

Abam, F.I., Briggs, T.A., Ekwe, B.E., Samuel, O. and Effiom, S.O. (2017). Investigation of intercooler-effectiveness on exergo-economic and exergosustainability parameters of modified Brayton cycles. Case Studies in Thermal Engineering, 10, 9-18.

Abam, F.I., Ekwe, E.B., Effiom, S.O. and Afangideh, C.B. (2018a). Performance and thermo-sustainability analysis of non-hybrid organic Rankine cycles (ORCs) at varying heat source and evaporator conditions. Australian Journal of Mechanical Engineering, 16(3), 238248.

Abam, F.I., Ekwe, E.B., Effiom, S.O. and Ndukwu, M.C. (2018b). A comparative performance analysis and thermo-sustainability indicators of modified low-heat organic Rankine cycles (ORCs): An exergy-based procedure. Energy Reports, 4, 110-118.

Abam, F.I., Ekwe, E.B., Effiom, S.O., Ndukwu, M.C., Briggs, T.A. and Kadurumba, C.H. (2018c). Optimum exergetic performance parameters and thermo-sustainability indicators of low-temperature modified organic Rankine cycles (ORCs). Sustainable Energy Technologies and Assessments, 30, 91-104.

Acar, C. and Dincer, I. (2014). Energy and Exergy Analyses of a Zero Emission Power Plant for Coproduction of Electricity and Methanol, in Dincer, I., Midilli, A. and Kucuk, H. (Eds.), Progress in Exergy, Energy, and the Environment, pp.145-156. Cham: Springer.

Ataei, A., Safari, F. and Choi, J.K. (2015). Thermodynamic performance analysis of different organic Rankine cycles to generate power from renewable energy resources. American Journal of Renewable and Sustainable Energy, 1(2), 31-38.

Aydin, H. (2013). Exergetic sustainability analysis of LM6000 gas turbine power plant with steam cycle. Energy, 57, 766-774.

Aydin, H., Turan, O., Karakoc, T.H. and Midilli, A. (2015). Exergetic sustainability indicators as a tool in commercial aircraft: A case study for a turbofan engine. International Journal of Green Energy, 12(1), 28-40. 
Aygun, H. and Turan, O. (2020). Exergetic sustainability off-design analysis of variable-cycle aero-engine in various bypass modes. Energy, 195, 117008.

Baklacioglu, T., Turan, O. and Aydin, H. (2018). Metaheuristic approach for an artificial neural network: Exergetic sustainability and environmental effect of a business aircraft. Transportation Research, Part D: Transport and Environment, 63, 445-465.

Balli, O. and Hepbasli, A. (2014). Exergoeconomic, sustainability and environmental damage cost analyses of T56 turboprop engine. Energy, 64, 582-600.

Balta, M. T., Dincer, I. and Hepbasli, A. (2010). Performance and sustainability assessment of energy options for building HVAC applications. Energy and Buildings, 42(8), 1320-1328.

Baral, S., Kim, D., Yun, E. and Kim, K. C. (2015). Experimental and thermoeconomic analysis of small-scale solar organic Rankine cycle (SORC) system. Entropy, 17(4), 2039-2061.

Caglayan, H. and Caliskan, H. (2018). Energy, exergy and sustainability assessments of a cogeneration system for ceramic industry. Applied Thermal Engineering, 136, 504-515.

Caliskan, H. and Hepbasli, A. (2011). Exergetic cost analysis and sustainability assessment of an internal combustion engine. International Journal of Exergy, 8(3), 310-324.

Caliskan, H., Hepbasli, A. and Dincer, I. (2011). Exergy analysis and sustainability assessment of a solar-ground based heat pump with thermal energy storage. Journal of Solar Energy Engineering, 133(1), 011005.

Chowdhury, T., Chowdhury, H., Chowdhury, P., Sait, S. M., Paul, A., Ahamed, J. U. and Saidur, R. (2020a). A case study to application of exergy-based indicators to address the sustainability of Bangladesh residential sector. Sustainable Energy Technologies and Assessments, 37, 100615 .

Chowdhury, H., Chowdhury, T., Hossain, N., Chowdhury, P., Salam, B., Sait, S. M., et al. (2020b). Exergetic sustainability analysis of industrial furnace: a case study. Environmental Science and Pollution Research, 28(10), $1-8$. 
Dincer, I. and Zamfirescu, C. (2018). Sustainable Dimensions of Energy, in Dincer, I. (Ed.), Comprehensive Energy Systems, Volume 1: Energy Fundamentals, pp. 102-151. Amsterdam: Elsevier.

Ekici, S., Sohret, Y., Coban, K., Altuntas, O. and Karakoc, T.H. (2018). Sustainability metrics of a small scale turbojet engine. International Journal of Turbo \& Jet-Engines, 35(2), 113-119.

Gabrielsen, P. and Bosch, P. (2003). Environmental Indicators: Typology and Use in Reporting. https://www.researchgate.net/publication/237573469_Environmental_Ind icators_Typology_and_Use_in_Reporting. Access Date: 01.03.2019.

Gingerich, D.B. and Mauter, M.S. (2015). Quantity, quality, and availability of waste heat from United States thermal power generation. Environmental Science \& Technology, 49(14), 8297-8306.

Hacatoglu, K., Dincer, I. and Rosen, M.A. (2015). A new model to assess the environmental impact and sustainability of energy systems. Journal of Cleaner Production, 103, 211-218.

Jankowski, M. and Borsukiewicz, A. (2020). A novel exergy indicator for maximizing energy utilization in low-temperature ORC. Energies, 13(7), 1598 .

Kalikatzarakis, M. and Frangopoulos, C. (2015). Multi-criteria selection and thermo-economic optimization of organic Rankine cycle system for a marine application. International Journal of Thermodynamics, 18(2), 133141.

Konur, O., Saatcioglu, O.Y., Korkmaz, S.A., Erdogan, A. and Colpan, C.O. (2020). Heat exchanger network design of an organic Rankine cycle integrated waste heat recovery system of a marine vessel using pinch point analysis. International Journal of Energy Research, 44(15), 12312-12328.

Kristensen, P. (2004). The DPSIR Framework. https://wwz.ifremer.fr/dce/content/download/69291/913220/ .../DPSIR.pdf, Access Date: 12.04.2021.

Linde Industrial Gases. (2021). Refrigerants. https://www.lindegas.com/en/products_and_supply/refrigerants/index.html, Access Date: 16.01.2021. 
Linke, B., Das, J., Lam, M. and Ly, C. (2014). Sustainability indicators for finishing operations based on process performance and part quality. Procedia CIRP, 14, 564-569.

Maniali, B. and Silveira, S. (2015). Using a sustainability index to assess energy technologies for rural electrification. Renewable and Sustainable Energy Reviews, 41, 1351-1365.

Midilli, A., Kucuk, H. and Dincer, I. (2012). Environmental and sustainability aspects of a recirculating aquaculture system. Environmental Progress \& Sustainable Energy, 31(4), 604-611.

Nami, H. and Anvari-Moghaddam, A. (2020). Small-scale CCHP systems for waste heat recovery from cement plants: thermodynamic, sustainability and economic implications. Energy, 192, 116634.

Ness, B., Urbel-Piirsalu, E., Anderberg, S. and Olsson, L. (2007). Categorising tools for sustainability assessment. Ecological Economics, 60(3), 498-508.

Ozcan, H. and Dincer, I. (2014). Thermodynamic Analysis of a Solar Driven Tri-Generation System for Building Applications, in Dincer, I., Midilli, A. and Kucuk, H. (Eds.), Progress in Exergy, Energy, and the Environment, pp. 169-180. Cham: Springer.

Refrigerant Report. (2020). Refrigerant Report. https://www.bitzerrefrigerantreport.com/fileadmin/user_upload/A-501-20.pdf, Access Date: 16.01.2021.

Rosen, M.A. and Dincer, I. (2001). Exergy as the confluence of energy, environment and sustainable development. Exergy, An International Journal, 1(1), 3-13.

Rosen, M.A., Dincer, I. and Kanoglu, M. (2008). Role of exergy in increasing efficiency and sustainability and reducing environmental impact. Energy Policy, 36(1), 128-137.

Sahu, M.K., Choudhary, T., Kumari, A. and Sanjay, R. (2018). Thermoeconomic, sustainability and environmental damage cost analysis of air cooled CT7-7A turboprop engine. SAE Technical Paper, 2018-01-0774(2018), 1-12. 
Sögüt, M.Z. (2018). Exergetic irreversibility and sustainability performances for alternative fuels in the micro-turbojet engine. International Journal of Green Energy, 15(3), 169-180.

Srinivasan, R.S., Braham, W.W., Campbell, D.E., Curcija, D.C. and Rinker, M.E. (2011). Sustainability assessment frameworks, evaluation tools and metrics for buildings and its environment - A review. In: Proceedings of Building Simulation: 12th Conference of International Building Performance Simulation Association. Sydney, Australia.

Stougie, L. (2014). Exergy and sustainability: Insights into the value of exergy analysis in sustainability assessment of technological systems. Ph.D. Thesis, Delft University of Technology, Delft.

Stougie, L., Tsalidis, G.A., van der Kooi, H.J. and Korevaar, G. (2018). Environmental and exergetic sustainability assessment of power generation from biomass. Renewable Energy, 128, 520-528.

Şöhret, Y., Ekici, S., Altuntaş, Ö., Hepbasli, A. and Karakoç, T.H. (2016). Exergy as a useful tool for the performance assessment of aircraft gas turbine engines: A key review. Progress in Aerospace Sciences, 83, 57-69.

Tsougranis, E.L. and Wu, D. (2018). A feasibility study of organic Rankine cycle (ORC) power generation using thermal and cryogenic waste energy on board an LNG passenger vessel. International Journal of Energy Research, 42(9), 3121-3142.

Turan, O. and Aydin, H. (2016). Exergy-based sustainability analysis of a low-bypass turbofan engine: a case study for JT8D. Energy Procedia, 95, 499-506.

Turan, O., Aydin, H., Karakoc, T.H. and Midilli, A. (2014). Some exergetic measures of a JT8D turbofan engine. Journal of Automation and Control Engineering. 2(2), 110-114.

Visentin, C., da Silva Trentin, A.W., Braun, A.B. and Thomé, A. (2020). Life cycle sustainability assessment: a systematic literature review through the application perspective, indicators, and methodologies. Journal of Cleaner Production, 270(2020), 122509.

Wall, G. (1997). Exergy use in the Swedish society. In: Proceedings of the International Conference on Thermodynamic Analysis and Improvement of Energy Systems. Beijing, China. 
Walter, M. (2013). DPSIR. http://www.ejolt.org/2013/02/dpsir/, Access Date: 30.01.2021.

Wu, X.F., Chen, G.Q., Wu, X.D., Yang, Q., Alsaedi, A., Hayat, T. and Ahmad, B. (2015). Renewability and sustainability of biogas system: cosmic exergy based assessment for a case in China. Renewable and Sustainable Energy Reviews, 51, 1509-1524.

Yuksel, B., Balli, O., Gunerhan, H., Hepbasli, A. and Atalay, H. (2020). Exergetic and Environmental Analyses of Turbojet Engine, in Colpan, C.O. and Ezan, M.A. (Eds.), Environmentally-Benign Energy Solutions, pp. 387-401. Cham: Springer. 